\title{
Effect of substitution of lime stone in CPJ45 by Jorf Lasfer fly and bottom ash on the hydration of cement and on the mechanical proprieties of mortar
}

\author{
K. Nabih ${ }^{1}$, R. Barbacha ${ }^{1}$, Ángeles G. De la Torre ${ }^{2}$, O.Sassi ${ }^{3}$, K.Kada $^{4}$ and F.Cherkaoui El-Moursli ${ }^{5}$ \\ ${ }^{1}$ Laboratory of Applied Solid State Chemistry, Department of chemistry, \\ University of Mohammed V-Agdal, Faculty of Science, B.P. 1014 Rabat, Morocco \\ ${ }^{2}$ Departamento de Química Inorgánica, Cristalografía y Mineralogía, Universidad de Málaga, Spain \\ ${ }^{3}$ Laboratory of Physico-Chemical of Materials, ENS, Takaddoum B.P.5118, Rabat, Morocco \\ ${ }^{4}$ Laboratory Asment Temara (Groupe Votorantim) Ain Atig-Temara, Rabat, Morocco \\ ${ }^{5}$ Laboratory of Materials Chemistry, Chemistry Department, University Mohammed V-Agdal, B.P. 1014 Rabat, Morocco
}

\section{Khadijanabih@yahoo.fr}

\begin{abstract}
The study undertaken in this work indicates that it is possible to exploit the industrial by products such as fly ash and bottom ash from the combustion of coal in Jorf lasfar thermal power and valorize them as additive in the construction materials. Because in addition to their poozolanic activity, these ashes have technical, economical and ecological compelling interests.

In this work we have studied the effects of substitution of limestone in the CPJ45 cement by fly ash or bottom ash on the mechanical properties of prepared mortars, on the grinding time and on the hydration of the new cements.

Different analysis techniques were undertaken to determine the physico-chemical characteristics of the starting materials.

$\mathrm{X}$-ray fluorescence (XRF) had permitted the classification of fly ash and bottom ash in the class $\mathrm{F}$ from their levels on major oxides. Rietveld quantitative phase analysis (RQPA) allowed us to compare the percentages of clinker phases with that calculated with bogue formulas. The result showed that the values found by RQPA of $\mathrm{C}_{3} \mathrm{~S}$ and $\mathrm{C}_{3} \mathrm{~A}$ were much higher than those calculated, while for the $\mathrm{C}_{2} \mathrm{~S}$ the values given by RQPA were much lower.

The isothermal conduction micro calorimeter was used to measure the heat evolution during the hydration of the cements prepared. We noticed that the additions of fly ash or bottom ash have accelerated the hydration of $\mathrm{C}_{3} \mathrm{~A}$ and have delayed that of $\mathrm{C}_{3} \mathrm{~S}$.

The tests performed by substituting limestone in $\mathrm{CPJ}_{45}$ by different proportions of fly ash or bottom ash have shown that the effect of these ashes on the mechanical properties of cement $\mathrm{CPJ}_{45}$. We have observed that the 28 days mechanical strengths of the mortar went for a maximum with the substitution of lime stone by $6 \%$ of fly ash and $7 \%$ of bottom ash;

We have also observed that increasing the amount of substitution of lime stone by fly ash had decreased the grinding time and had eliminated the clogging of the cement on the mill balls.
\end{abstract}

\section{Introduction}

The Moroccan cement industry is a major player in the development of the country because growing needs for cementing products for the construction of buildings and communication infrastructures are considerable. This industry participates with $1.2 \%$ of gross domestic products.

Among the goal chosen to optimize the production of cement is the focus more towards the manufacture of cement with addition of industrial by products such as fly and bottom ash, that are known to be of great interest in cement and concrete.

These ashes have hydraulic and poozolanic activities and have the potential to improve the durability of concrete [1-2]. Kokubu established that partial replacement of cement by a good quality fly ash increases the workability. typically, to produce a concrete with the same 28-days strength as one made using a pure Portland cement [3].Uchikawa reviewed rheological studies of Fly ash containing a high proportion of coarse ash ( $>45 \mathrm{um})$ and mentioned that these materials are unsuitable for blending but may be suitable for inter grinding, because the effect of the latter is largely to separate particles present in agglomerates and to break up some of the larger cenospheres [4].

In Morocco, the production of fly ash from thermal power plants is estimated at 570000 tons per year (400,000 tons are recoverable in the dry state). The use of these ashes in cement can protect the environment by reducing the $\mathrm{CO}_{2}$ emissions [5] and conserving the raw materials. Such utilization of these by products is a good example to provide a solution to environment problems for the storage of these wastes and improve the thermal balance in an area of high energy consumption. 


\section{Materials and methods}

The materials used in the preparation of the cement studied are the same as those used in the manufacturing process of cement in the plant Asment Temara (Votorantim group).Limestone was crushed and then dried at $110^{\circ} \mathrm{C}$ and the gypsum was dried at a temperature which does not exceed $60^{\circ} \mathrm{C}$. Both materials were crushed by a vibro-mill oscillating disc SIEBTECHNIK kind.

The clinker was recovered directly from the cooler outlet factory. Fly ash and bottom ash are the residues from the combustion of coal in Jorf Lasfar thermal power.

The clinker was crushed by a jaw crusher (Fritsh pulverisette kind 01-703) and homogenized to a uniform particle sizes

\subsection{Determination of refusal}

To avoid the influence of the fineness on the mechanical properties of mortars in our study, we had set the refusal of cements to 80 microns between 2.2 and 2.7\%. This refusal was controlled by an Alpine sieve

\subsection{X-ray fluorescence (XRF)}

The chemical analysis of the materials used in this study was determined using a spectrometer PanAnalytical PW 4400/24 in Asment Temara laboratory.

\subsection{X-ray diffraction (XRD)}

The crystalline phases of fly ash, bottom ash and clinker were identified by a diffractometer using the Bragg-Brentano assembly and radiation $\mathrm{K} \alpha \mathrm{Cu} 1.5406 \mathrm{~A}{ }^{\circ}$, with a range of spectra between 10 and $60^{\circ}$ and a pitch of 0.04 in department of inorganic, mineral chemistry and crystallography at the university of Malaga, Spain.

\subsection{Preparation of mortar}

For the determination of compressive and bending strengths, mortars were prepared by mixing one part of cement, and three parts of standard sand with a ratio water to cement of 0.5 . Specimens of prismatic shape with dimensions $40 \mathrm{~mm} \times 40 \mathrm{~mm} \times 160 \mathrm{~mm}$ were taken from the mortar.

\subsection{Conduction calorimetric}

The conduction microcalorimetry has been helpful to measure the evolution of heat during hydration of our samples. In this study a specific assembly adapted to differential microcalorimeter Tian-Calvet type operating in isothermal was used (Laboratory of Physical Chemistry of Materials, ENS, Takaddoum, Rabat)

The tests were carried out with $1 \mathrm{~g}$ of each sample. The water / solid ratio was equal to 0.5 at $26^{\circ} \mathrm{C}$.

\section{Results and discussions}

\subsection{Analysis by X-ray fluorescence (XRF)}

The results of X-ray fluorescence analysis of the various chemical components of different samples: clinker, limestone, fly ash and bottom ash are summarized in Table.1a. We note that the fly ash and the bottom ash of Jorf Lasfer are rich in $\mathrm{SiO}_{2}$ and $\mathrm{Al}_{2} \mathrm{O}_{3}$ with a high percentage on $\mathrm{Fe}_{2} \mathrm{O}_{3}$ and low on $\mathrm{CaO}$. The sums of their oxides are respectively 86.85 and 83.59 . We classify these ashes as silicoaluminous class $\mathrm{F}$, with pozzolanic properties. The U.S. designation of Class $\mathrm{F}$ fly ash is based on their compositions $\mathrm{SiO}_{2}, \mathrm{Al}_{2} \mathrm{O}_{3}$ and $\mathrm{Fe}_{2} \mathrm{O}_{3}$, the sum must be greater than $70 \%$ with a low percentage of $\mathrm{CaO}$ [6]. From the same table we can see that $\left(\mathrm{K}_{2} \mathrm{O} / \mathrm{Al}_{2} \mathrm{O}_{3}\right) \cdot 10$ is equal to 1.006.. According to Hubbard et al, there is a high correlation between $\mathrm{K}_{2} \mathrm{O} / \mathrm{Al}_{2} \mathrm{O}_{3}$ ratio and the percentage of amorphous aluminosulphates that Greatly contribute to the pozzolanic reaction. They have suggested that this ratio multiplied by 10 can be used as an index of the pozzolanic potential [7]. The chemical composition of Asment clinker on major and minor oxides $\mathrm{SiO}_{2}, \mathrm{Al}_{2} \mathrm{O}_{3}, \mathrm{Fe}_{2} \mathrm{O}_{3}, \mathrm{CaO} \mathrm{MgO}$, $\mathrm{SO}_{3}$ and the mineralogical composition of the Asment clinker calculated by Bogue formulas $\mathrm{C}_{3} \mathrm{~S}(62,99), \mathrm{C}_{2} \mathrm{~S}(13,14), \mathrm{C}_{3} \mathrm{~A}(7,91)$ and $\mathrm{C}_{4} \mathrm{AF}(9,41)$ are in the average values of an ordinary Portland clinker [8]. From table 1-b we can see that the total organic carbon for fly ash is less than 0.5 and the percentage of reactive silica is greater than 25 and reactive $\mathrm{Ca} 0$ content is very low.

The results of the XRF analysis of gypsum and limestone that were used in our study have shown that the purity of the gypsum is of the order of $87.18 \%$ and the percentage by mass of $\mathrm{SO}_{3}$ is $40.55 \%$.

\subsection{Determination of free lime}

The determination of free lime is an essential parameter for judging the quality and degree of clinker cooking. Well cooked clinkers resulting from a well balanced raw materials and good particles size content less than $2 \%$ of free lime. Above $2 \%$ of free lime quantity modifies the mechanical properties of the cement, and cause it to swell as they form $\mathrm{Ca}(\mathrm{OH})_{2}$.

For the studied clinker we found a value for the free lime equal to $0.89 \%$. We can confirm that our clinker had no negative influence on the mechanical properties of cement studied, and that its quality meets the requirements of the standard Moroccan [NM 10.1.004].

\subsection{Analysis by X-ray diffraction (XRD)}

We observe from (RQPA) fly ash normalized to $100 \%$ (Fig. 1 and table 2) that the crystalline phase of this ash is composed of $20.1 \%$ of mullite, $9.2 \%$ quartz and $0.4 \%$ of hematite. The existence of a halo between 2 Theta $\left(21^{\circ}-30^{\circ}\right)$ is characteristic of the presence of a glassy phase. RQPA shows that the crystalline fraction is about 29.7 (Table 2) which means that the ash of Jorf Lasfar contain a high proportion of active ingredient in glass form. From X rays diffraction (Fig.2) we observe the different phases of Asment clinker. The quantitative 
Rietveld analysis (RQPA) allowed us to compare the percentages of clinker phases with that found by bogue calculation. From RQPA we found that for $\mathrm{C} 3 \mathrm{~S}$ the value is much higher than the one calculated by Bogue formulas, while for the $\mathrm{C} 2 \mathrm{~S}$ and $\mathrm{C} 3 \mathrm{~A}$ the values calculated by latest formulas are greater (Table 3).According to some scientists, Bogue calculation generally gives lower values for alite and higher values for belite and tricalcium aluminates. This is due to the thermodynamic equilibrium which was not reached in the furnace. Bogue calculations are based on thermodynamic equilibrium and do not take into account the existence of impurities (eg $\mathrm{Mg}$ in alite) [8].The RQPA value obtained by C3A is the fraction of the crystalline phase. This result confirms that clinker must contain an amorphous $\mathrm{C} 3 \mathrm{~A}$ fraction. The crystalline fractions of $\mathrm{CaO}$ and $\mathrm{MgO}$ are respectively 0.6 and 0.3 (Table 3)

Table 1-a: Chemical compositions of the starting materials

\begin{tabular}{|c|c|c|c|c|}
\hline Oxides & Clinker & $\begin{array}{c}\text { Lime } \\
\text { stone }\end{array}$ & Fly ash & Bottom ash \\
\hline $\mathrm{SiO2}$ & 21.17 & 14.26 & 56.24 & 54.6 \\
\hline $\mathrm{Al}_{2} \mathrm{O}_{3}$ & 4.96 & 0.99 & 26.49 & 21.3 \\
\hline $\mathrm{Fe}_{2} \mathrm{O}_{3}$ & 3.09 & 1.28 & 4.12 & 7.69 \\
\hline $\mathrm{CaO}$ & 65.34 & 46.07 & 2.42 & 4.51 \\
\hline $\mathrm{MgO}$ & 2.02 & 0.55 & 0.73 & 1.58 \\
\hline $\mathrm{SO}_{3}$ & 1.54 & 0.23 & -0.03 & -0.02 \\
\hline $\mathrm{K}_{2} \mathrm{O}$ & 0.83 & 0.16 & 2.67 & 1.87 \\
\hline $\mathrm{TiO}_{2}$ & 0.39 & 0.18 & 1.27 & 0.90 \\
\hline $\mathrm{MnO} \mathrm{O}$ & 0.08 & 0.04 & 0.02 & 0.07 \\
\hline $\mathrm{P}_{2} \mathrm{O}_{5}$ & 0.26 & 0.26 & 0.11 & 0.41 \\
\hline $\mathrm{Na}_{2} \mathrm{O}$ & -0.01 & 0.02 & 0.00 & 0.09 \\
\hline
\end{tabular}

Table 1-b: Analysis of fly ash and limestone by LPEE(public testing laboratory and studies) [Test Report No. 13/153.5/832]

\begin{tabular}{|c|c|c|c|}
\hline & $\begin{array}{c}\text { Réf LPEE } \\
153 / 852 / 1\end{array}$ & $\begin{array}{c}\text { Réf LPEE } \\
153 / 852 / 2\end{array}$ & $\begin{array}{c}\text { Specification } \\
\text { NM 10.1004 }\end{array}$ \\
\hline Détermination & limestone & Fly ash & \\
\hline $\begin{array}{c}\text { Total organic } \\
\text { carbon in\% }\end{array}$ & $0.10 \pm 0.05$ & $\leq 0.5$ \\
\hline Clay content & $1.55 \pm 0.22$ & & $\leq 2$ \\
\hline $\begin{array}{c}\text { Reactive silica } \\
\text { (SiO2r) in\% }\end{array}$ & - & $48.81 \pm 4.12$ & $\geq 25$ \\
\hline $\begin{array}{c}\text { reactive lime } \\
(\text { CaOr) in\% }\end{array}$ & - & $1.12 \pm 0.08$ & $\leq 10$ \\
\hline
\end{tabular}

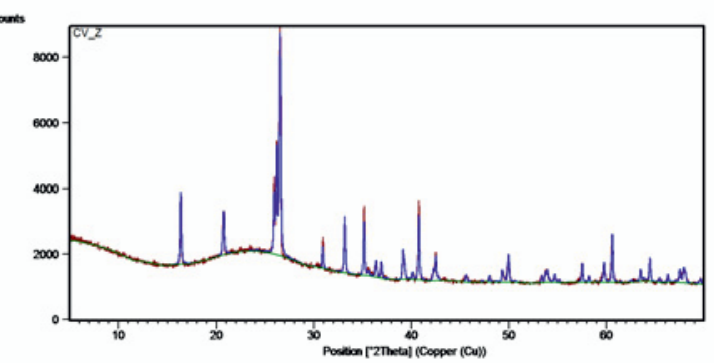

Figure 1: Diagram of X-ray diffraction of fly ash Results Quantified by the Rietveld method

\subsection{Effect of ash on the grinding time}

During the preparation of different types of cement produced by grinding CPJ45(75\% clinker, 22\% lime stone, and $3 \%$ gypsum) with the substitution of lime stone by fly ash with a filling degree of $25 \%$ of the mill. We had observed that the decrease in the grinding time is proportional to the increase of the percentage of fly ash that replaced lime stone.

Table 4 and figure 3 show that for the same refusal, the evolution of milling time has been greatly reduced. This reduction in time is due to the abrasive effect of the grains of ashes on thegrains of the clinker, which leads to the production of a large fraction of very fine particles. Bombled studied the effect of fly ash on the grinding time and concluded that the reduction in grinding time is probably related to the high content of $\mathrm{SiO} 2$ in fly ash [9].

Table 2: The percentage of crystalline and non-crystalline phases of Jorf Lasfer ash quantified by the Rietveld method

\begin{tabular}{|l|l|}
\hline Chemical formulas & Cristalline phases \\
\hline $\mathrm{Al}_{2}\left(\mathrm{Al}_{2} .8 \mathrm{Si}_{1.2}\right) \mathrm{O}_{9.6}$ (Mullite) & 20.1 \\
\hline $\mathrm{SiO} 2$ (Quartz) & 9.2 \\
\hline $\mathrm{Fe} 2 \mathrm{O} 3$ (hématites) & 0.4 \\
\hline $\mathrm{ACn}^{*}$ & 70.2 \\
\hline
\end{tabular}

(* the fraction of the amorphous part and no quantified crystalline portion)

Table 3: Comparison between the values found by RQPA and those calculated by Bogue for Asment clinker phases

\begin{tabular}{|l|c|c|c|}
\hline $\begin{array}{l}\text { Chemical } \\
\text { formulas }\end{array}$ & $\begin{array}{c}\text { values } \\
\text { found } \\
\text { by } \\
\text { RQPA }\end{array}$ & $\begin{array}{c}\text { values } \\
\text { found by } \\
\text { Bogue } \\
\text { formulas }\end{array}$ & \\
\hline$\left(\mathrm{C}_{3} \mathrm{~S}\right)$ & $\begin{array}{c}76.1 \pm 0 . \\
9\end{array}$ & 62.84 & \\
\hline$\beta-\mathrm{C}_{2} \mathrm{~S}$ & $\begin{array}{c}11.3 \pm 0 . \\
9\end{array}$ & 13.39 & \\
\hline $\mathrm{C}_{4} \mathrm{AF}$ & $\mathbf{8 . 6 \pm 0 . 3}$ & 9.03 & \\
\hline $\mathrm{C}_{3} \mathrm{~A}-$ cubic & $\mathbf{3 . 2} \pm 0.2$ & 7.8 & \\
\hline $\mathrm{CaO}$ & $\mathbf{0 . 6} \pm 0.1$ & & $\begin{array}{c}\text { Cao (I) } \\
0.84\end{array}$ \\
\hline $\mathrm{MgO}$ & $\mathbf{0 . 3} \pm 0.1$ & - & $\begin{array}{c}\text { MgO } \\
\text { (totale) } \\
2.02\end{array}$ \\
\hline
\end{tabular}

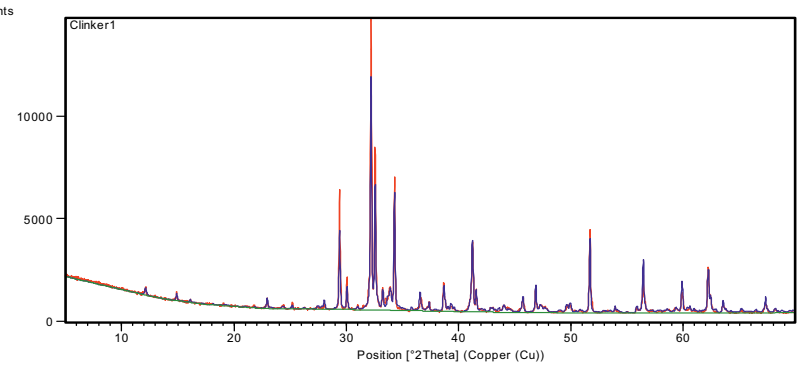

Figure 2: Diagram of X-ray diffraction of Asment.clinker. Results Quantified by the Rietveld method 
Table 4: Effect of fly ash on the grinding time of cement

\begin{tabular}{|c|c|c|c|c|c|c|c|c|c|}
\cline { 2 - 10 } \% Fly ash & $\mathbf{0}$ & $\mathbf{5}$ & $\mathbf{6}$ & $\mathbf{7}$ & $\mathbf{8}$ & $\mathbf{9}$ & $\mathbf{1 0}$ & $\mathbf{1 5}$ & $\mathbf{2 0}$ \\
\hline $\begin{array}{c}\text { Grinding } \\
\text { time (min) }\end{array}$ & 96 & 73 & 67 & 57 & 54 & 51 & 47 & 40 & 35 \\
\hline $\begin{array}{c}\text { Refusal to } \\
80 \text { microns } \\
\text { Weight\% }\end{array}$ & 2.4 & 2.6 & 2.3 & 2.6 & 2.9 & 2.2 & 2.4 & 2.4 & 2.7 \\
\hline
\end{tabular}

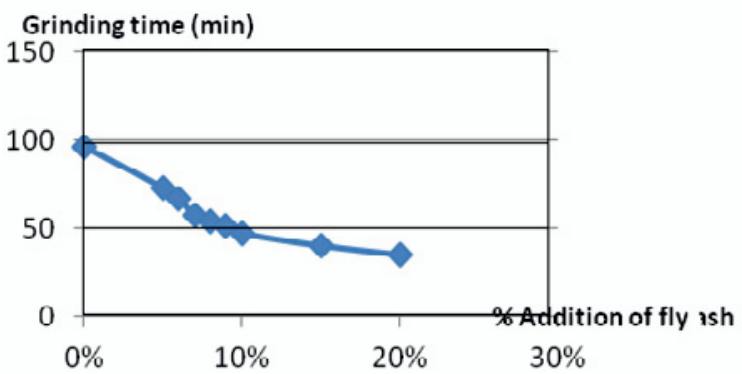

Figure 3: Effect of fly ash on the grinding time of cement

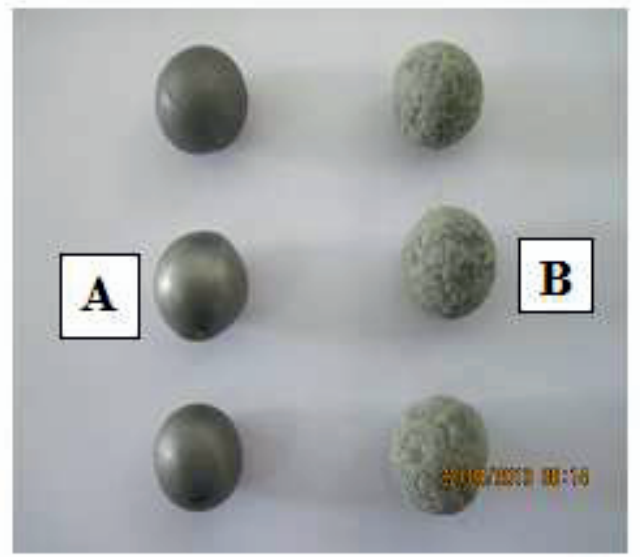

Photo :Effect of clogging of the mterial on the
ball mill(A) with the addition of fly ash (B) with
out the addition( 95 min of grinding)

The effect of fly ash on the balls of the mill was also studied and we noted that the balls are clean when fly ash is introduced into the mill photos 1 .

We see from photo 1 (B) three balls $20 \mathrm{~mm}$ diameter each wrapped with a thin layer of cement. These balls were recovered from the mill when there was no fly ash added. The three other balls 1 (A) are clean and not covered by cement. They were recovered after grinding cement with addition of fly ash. When the milling time is high, the fine powders produced tend to adhere to the vertical walls of the mill and to the surfaces of the balls, this occurs by the compaction of the powder by the grinding media, this phenomenon is called clogging. It will prevent further grinding because it will increase the refusal. According to some researchers, grinding cement with fly ash, prevent clogging around the balls which leads to an increase in the production and even finesse in the mill for the same energy consumption [10]. Stoltemberg mentioned that when the fly ash are ground with the clinker, the time required to obtain the same surface area as Portland cement is very low [11]

\subsection{Compressive strengths}

We note that the substitution of limestone by fly ash in cement $\mathrm{CPJ}_{45}$ did not affect very much the refusal to 80 microns. We remained in the specifications covered by Asment Temara cement. For all cements prepared the refusals to 80 microns sieve were between $2.2 \%$ and $2.7 \%$ (table 4 ), which avoided the problem of particle sizes on the mechanical strength. From the figures 4 and 6 we can notice that the substitution of lime stone by fly ash had decreased the bending and the compressive strengths after one day of mortar hydration. After 7 days no significant increase on resistances was noticed.

We can see from the figure 8 that the increase on resistance had enhanced after 28 days of hydration. The compressive strength of cements prepared with the substitution of lime stone with fly ash increased reaching their maximum (41.5 $\mathrm{MPa}$ ) with $6 \%$ of fly ash with a gain of $2.5 \mathrm{MPa}$ comparing to the lime cement. Above these values there is a gradual drop in resistances. With the substitution of lime stone with the bottom ash we notice a decrease of the resistance. After 90 days of hydration (Fig.8) the effects of both ashes were very important with a gain in strength of $12 \mathrm{MPa}$ with $6 \%$ of fly ash and $8.6 \mathrm{MPa}$ with $7 \%$ of bottom ash. According to $\mathrm{F}$. Dechner et al this gain in strength was related to pozoolanic reaction that occurred later than the consumption of portlandite and the increase of chemical shrinkage that already had started after 7 days of hydration [12].

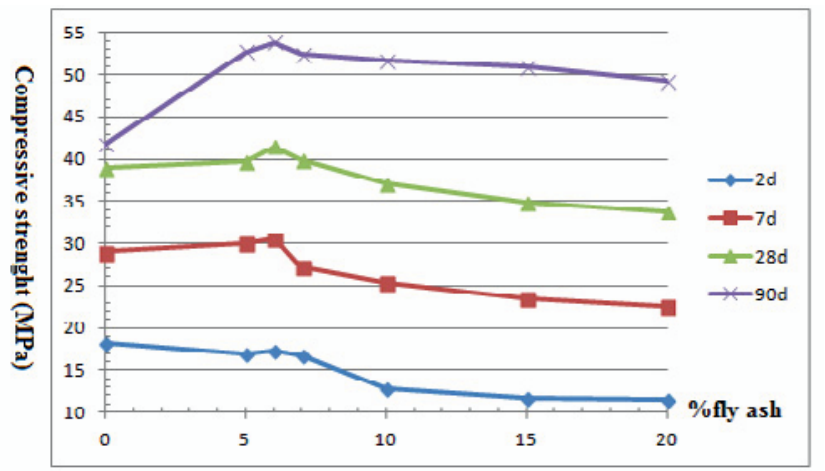

Figure 4: Evolution of compressive strenght with the Substitution of lime stone by fly ash in CPJ45

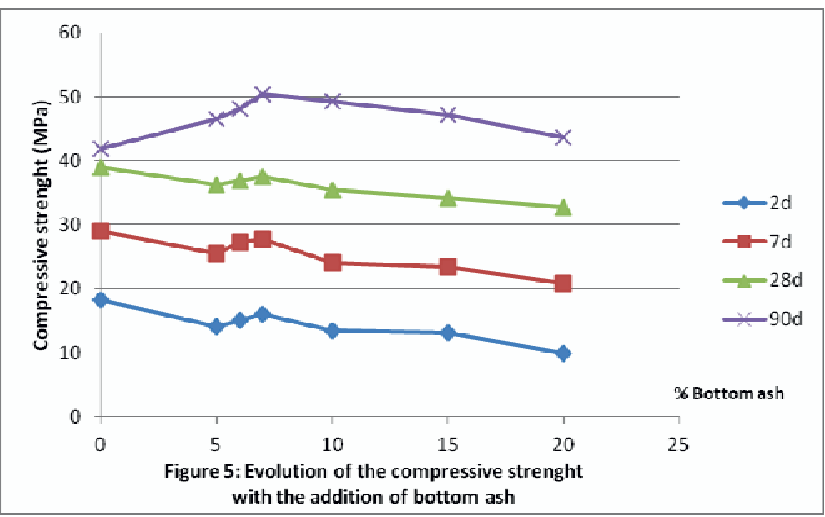




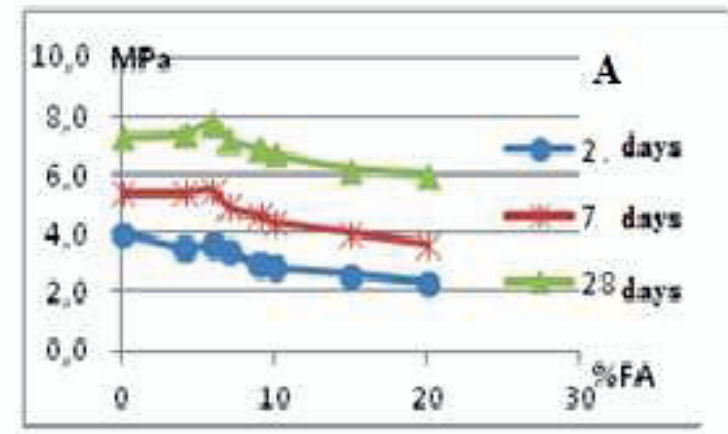

Figure 6:Erolution of bending strenght of cement with the addition of fly ash

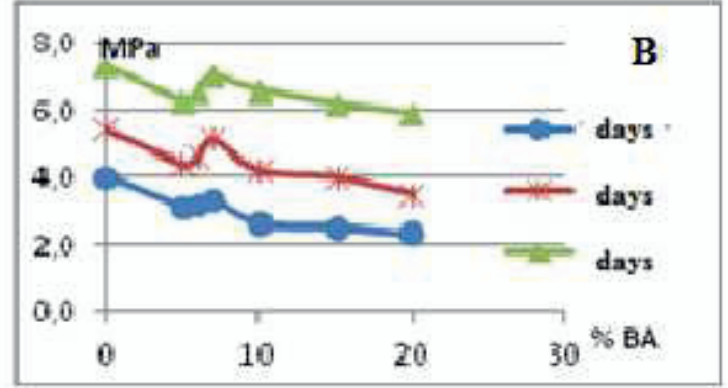

Figure 7: Evolution of bending strenght of cement by the addition of bottom ash

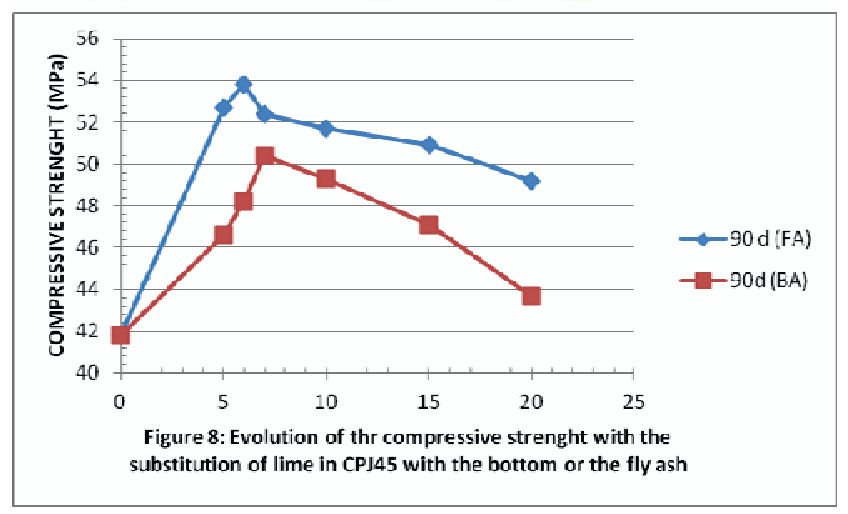

\section{6: Conduction calorimetric}

We have used the conduction calorimeter to follow the evolution of heat during hydration of our samples $\left(\mathrm{CPJ}_{45}\right.$ by the substitution of limestone with fly ash or bottom ash).Figures 9 and 10 show the rate of heat released during hydration of the three samples $\left(\mathrm{CPJ}_{45}\right.$ with $0 \%, 6 \%$ and $20 \%$ replacement of limestone by fly ash as a function of time. The heat evolution is that of an ordinary Portland clinker [13].The same figures show that during the first minutes following the injection of water, for each sample there is a heat evolution characterized by a first peak.

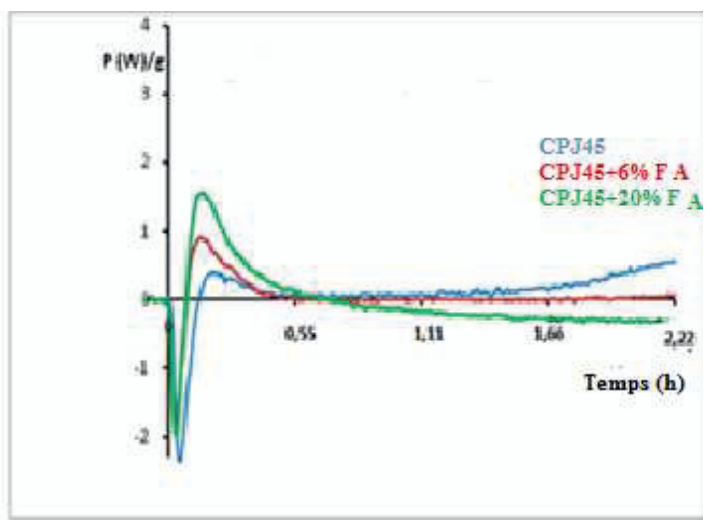

Fig. 9: First peak of heat of hydration of cement

CPJ45with the addition of fly ash

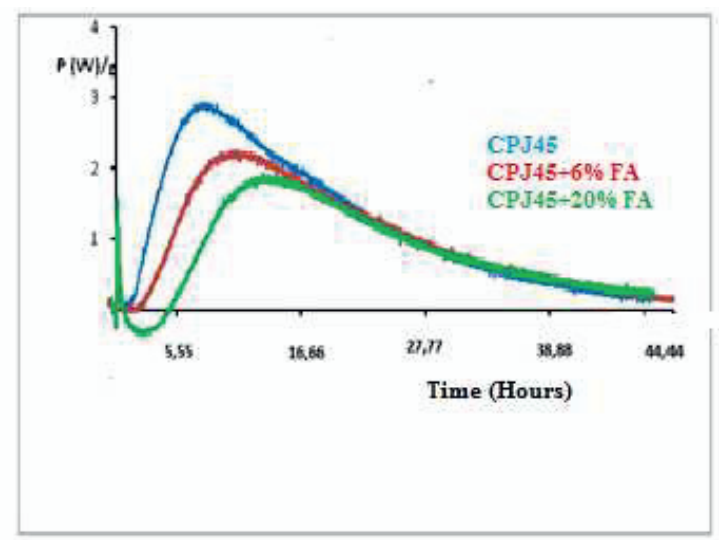

Figure 10: Effect of fly ash on the hydration of C3S in

$\mathbf{C P J}_{45}$

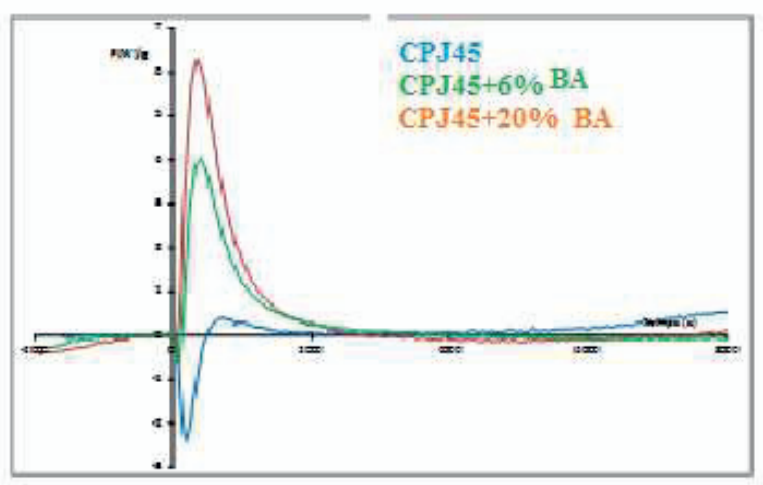

Figure 11: Effect of bottom ash on the first peak of hydration 


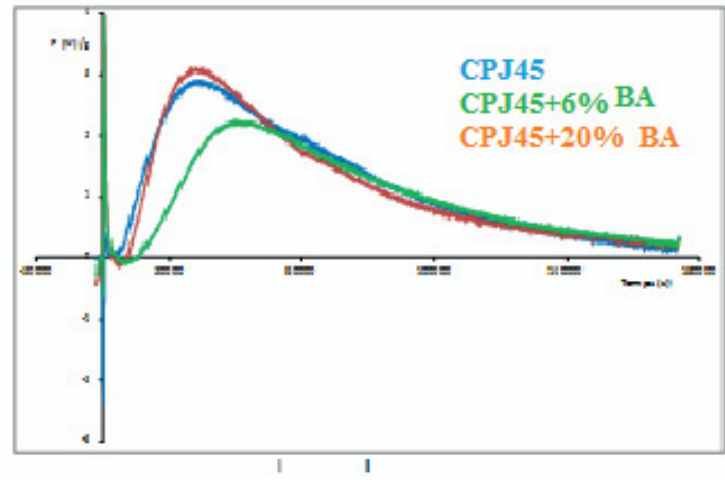

Figure 12: Effect of bottom ash on the second peak of hydration

The peak that characterizes the sample with $20 \%$ of substitution is much higher $(1.6 \mathrm{w} / \mathrm{g})$ than the $6 \%$ one $(0.8 \mathrm{w} / \mathrm{g})$ while the peak of $\mathrm{CPJ}_{45}$ is very low. $(0.4 \mathrm{w} / \mathrm{g})$ We note also that the hydration of $\mathrm{CPJ}_{45}$ is delayed for more than 8 minutes in comparison with that of CPJ with 6 or $20 \%$ of fly ash.

The first heat flow is followed by a period of very low reactivity which is longer for more than two hours for the substituted samples

Figure 10 shows for each sample a second hydration peak which is attributed to the hydration of $\mathrm{C}_{3} \mathrm{~S}$. The intensity of this peak decreases with the amount of fly ash added. We also observe that the addition of ash retards the hydration of $\mathrm{C}_{3} \mathrm{~S}$. By more than two hours and a half. This delay is very visible.

Some authors mentioned that addition of fly ash accelerates the hydration of $\mathrm{C}_{3} \mathrm{~S}[14,15]$ But the retarding effect on hydration by fly ash has been reported by other authors [16, 17]. According to Wel Tajoun et al, the retardation phenomenon is due to the ash surface that acts like a calcium sink, where calcium in solution is removed by the abundant aluminum associated with fly ash as an AFt phase preferentially formed on the surface of fly ash which slows additional Aft phase as a result of a longue induction period. Other authors have reported that the chemical and physical proprieties of fly ash particles surfaces such as chemical composition, mineral constitution, glass characteristics and reactivity delay $\mathrm{Ca}(\mathrm{OH})_{2}$ and $\mathrm{C}-\mathrm{S}-\mathrm{H}$ nucleation and crystallization witch retard cement hydration [ 14,16$]$.

The same behavior is shown in figure 11 and 12 for the hydration of samples where lime stone is substituted by bottom ash. We can see that the bottom ash enhance de hydration of the first peak and retard the heat evolution of the second peak but the retard of $\mathrm{C}_{3} \mathrm{~S}$ hydration is slightly less important than with fly ash substitution.

\section{Conclusion}

Jorf Lasfer fly and bottom ash has pozoolanic properties and belong to class F.

Substitution of lime stone with different amount fly ash or bottom ash in $\mathrm{CPJ}_{45}$ showed the following results:

-Fly ash give better mechanical properties compared to bottom ash and this is one more reason that Moroccan cement often use fly ash as an addition to cement or clinkers, because the fly ash is finer than bottom ash therefore require less energy for grinding.

-The best 90 days compression strength is attained by the substitution of lime stone in $\mathrm{CPJ}_{45}$ by $6 \%$ of fly ash or $7 \%$ of bottom ash.

-Grinding CPJ with fly ash reduce de milling time and prevent clogging around the balls in the mill which may leads to an increase in production at the mill for the same energy consumption.

-Increasing the substitution of lime stone by fly ash or bottom ash increased the reactivity of the first peak of hydration of the blended cement and reduced the intensity of the second peak with a delay of the reactivity of $\mathrm{C}_{3} \mathrm{~S}$.

\section{References}

1. . A. Shayan et al, concrete,Cem. Concr. Res. 26 153164, (1996)

2. . S.Q. Li, D.M. Roy, Cem. Concr. Res. 16 749-759. (1986)

3. . Kokubu, M., in 5th ISCC,. 4, 75 (1969).

4. . Uchikawa, H., in 8th ICCC, 1, 249 (1986).

5. Gartner. Cem.Concr.Res. 34 1489-1498. (2004)

6. . H.F.W. Taylor Cement chemistry2nd edition Thomas Telford edition published, 272; (1997)

7. . Hubbard, et al,. Cem. Concr. Res. 15, 185(1985)

8. .Lea's chemistry of cement and concrete 4th, ed by P.C.Hewlett, 154-156(2003)].

9. . J.P.Bombled, Proc;Int.Congr.Chem.,8th,.IV, Riode Janeiro, Brazil, 190-196 (1986)

10. . N. Buzoubaa et al,Cem.Congr.Res, 28 , 1555$1569,(1998)$

11. . E.Stolenberg-hanson, Rock Products, 87-89 (1984)

12. F.Deschner, Cem.Concr.Res., 42,1389-1400( 2012)

13. J. Bested, Advances in Cement Research, jNo,1(1987)

14. . K.Ogawa et al, Cem.Concr.Res. 10 (5), 863, (1980)

15. .N.Kawada et al, Sement Gijutsu Nempo.22, 124 ( 1968)

16. .I.Jawad et al, Cem.Congr.Res, , 15174- 184 (1985)

17. . J.G.cabrera et al, 7 th Int.Cong Chem.Cem.3, IV-85, (1980) 